\title{
PERBANDINGAN KINERJA KEUANGAN BPRS DAN BPR KONVENSIONAL DI SURABAYA
}

Nadia Sarasyanti

Program Studi Ekonomi Islam-Fakultas Ekonomi dan Bisnis-Universitas Airlangga

E-mail : nadia.sarasyanti-13@feb.unair.ac.id

Atina Shofawati

Departemen Ekonomi Syariah-Fakultas Ekonomi dan Bisnis-Universitas Airlangga

E-mail : atina-o@feb.unair.ac.id

\begin{abstract}
This study aimed to compare the financial performance of The Conventional Rural Bank (BPR) and Islamic Rural Bank (BPRS) in Surabaya. The Sample is acquired using saturate method. The writer selects all Islamic Rural Bank (BPRS) and Conventional Rural Bank (BPR) in Surabaya with in the year of 2014 - 2016. Methods of data analysing using independent Samples T - Test and Mann Whitney Experiment. The results of this research shows that there $i$ significant differences upon NPF or NPL ratio, FDR or LDR ratio, ROA, NIM or NOM, and CAR. Generally, on the aspec of Risk Profile, Earning, and Capital point of view, financial performances of the Conventional Rural Bank (BPR) showed that financial performances is better than the Islamic Rural Bank (BPRS).
\end{abstract}

Keywords: Comparison financial performance, the Conventional Rural Bank (BPR), the Islamic Rural Bank.

\section{PENDAHULUAN}

Industri Perbankan di Indonesia sangat penting peranannya dalam perekonomian suatu negara sebagai lembaga perantara keuangan. Hal ini dikarenakan perbankan merupakan salah satu lembaga yang mempunyai peran untuk mempertemukan antara pemilik dan pengguna dana, oleh karena itu, kegiatan bank harus berjalan secara efisien pada skala makro maupun mikro. Dana hasil mobilitas masyarakat dialokasikan ke berbagai ragam sektor eknomi dana keseluruhan area yang membutuhkan secara cepat dan tepat.

Menurut Undang - Undang

Perbankan No. 7 tahun 1992 yang disempurnakan menjadi Undang Undang No. 10 tahun 1998, pada pasal 5 disebutkan bahwa bank di Indonesia dibagi menjadi dua jenis yaitu bank umum dan bank perkreditan rakyat.

Di Indonesia terdapat dua jenis perbankan, yaitu bank yang melakukan kegiatan usaha secara konvensional dan bank yang melakukan kegiatan usaha secara syariah. Bank konvensional adalah bank yang melakukan kegiatan usaha secara konvensional dan kegiatan usahanya berdasarkan pada pembayaran bunga serta lebih dulu muncul dan berkembang di Indonesia. Sedangkan bank syariah adalah bank yang beroperasi berdasarkan prinsip prinsip Islam, yaitu mengedepankan keadilan, kemitraan, keterbukaan, dan universalitas bagi seluruh kalangan [1] Jurnal ini merupakan bagian dari Skripsi Nadia Sarasyanti NIM 041311433171 yang diuji pada tanggal 10 April 2017 
Sarasyanti, et al/Jurnal Ekonomi Syariah Teori dan Terapan Vol. 5 No. 4 April 2018: 290-304;

PERBANDINGAN KINERJA KEUANGAN BPRS DAN BPR KONVENSIONAL DI SURABAYA

(Laksamana, 2009:10) Pada bank syariah keadilan dapat terjadi dengan penerapan sistem bagi hasil dalam memberikan keuntungan bagi para nasabah dan pihak bank. Sistem bagi hasil adalah suatu sistem perbankan syariah yang tidak mengandung unsur riba dalam memberikan imbal hasil. Antonio (2001:37) menyatakan bahwa menurut istilah teknis riba berarti pengambilan tambahan dari harta pokok atau modal secara batil. Oleh sebab itu, riba diharamkan dalam transaksi apapun. Larangan pengembalian harta secara batil terdapat firman-Nya sebagai berikut: أَيْهَ

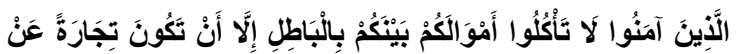

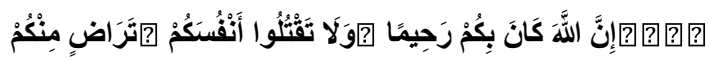
Yā 'Ayyuhā al-Lażina 'Āman̄̄ lā Ta'kulū 'Amwālakum bainakum bi al-Bāṭili 'illa 'an Takūna Tijāratan 'an Tarā ḍin Minkum wa lā Taqtulū 'Anfusakum 'inna Allāha Kāna bikum Rahīmāan.

Artinya:Hai orang-orang yang beriman, janganlah kamu saling memakan harta sesamamu dengan jalan yang batil, kecuali dengan jalan perniagaan yang berlaku dengan suka sama-suka di antara kamu. dan janganlah kamu membunuh dirimu.

Menurut Quth (2001:341) menyatakan bahwa terdapat larangan dalam memakan harta sesamanya secara bathil bagi orang beriman karena tindakan tersebut merupakan tindakan yang dapat membunuh jiwa, kehancuran dan kebinasaan.

Bank Perkreditan Rakyat (BPR) adalah bank yang melaksanakan kegiatan usaha perbankan secara konvensional atau berdasarkan prinsip syariah yang dalam kegiatannya tidak memberikan jasa dalam lalu lintas pembayaran. Muhammad (2002:13)

Persaingan BPR dan BPRS tidak bisa terhindarkan dan memberikan dampak yang mempengaruhi tumbuh kembangnya suatu bank. Sebuah bank harus mampu meningkatkan kinerja keuangannya untuk bisa bertahan dan mengembangkan eksistensinya. Kinerja keuangan bank merupakan salah satu keberhasilan kesehatan suatu bank, penilaian kinerja keuangan bank dapat dilakukan dengan menganalisis laporan kevangannya. Selain itu, Arifin (2005: 65) menjelaskan bahwa laporan keuangan (financial statement) menyimpulkan kegiatan dalam setiap bidang fungsional perbankan. Tingkat Kesehatan Bank merupakan hasil penilaian kualitatif atas berbagai aspek yang berpengaruh terhadap kondisi atau kinerja bank dengan melakukan penilaian terhadap faktor finansial dan faktor manajemen. Penilaian faktor finansial dilakukan dengan melakukan pembobotan terhadap peringkat faktor permodalan, kualitas aset, rentabilitas, likuiditas dan sensitivitas atas risiko pasar.

\section{Landasan Teori}

\section{Bank Perkreditan Rakyat}

\section{Bank Pembiayaan Rakyat Syariah}

Muhammad (2002:13) menjelaskan bahwa Bank Pembiayaan Rakyat Syariah adalah lembaga keuangan yang usaha pokoknya memberikan pembiayaan dan 
Sarasyanti, et al/Jurnal Ekonomi Syariah Teori dan Terapan Vol. 5 No. 4 April 2018: 290-304;

PERBANDINGAN KINERJA KEUANGAN BPRS DAN BPR KONVENSIONAL DI SURABAYA

jasa - jasa lainnya dalam lalu lintas pembayaran serta peredaran vang yang pengoperasiannya disesuaikan dengan prinsip syariah Islam. Pengertian beroperasi dengan syariah Islam adalah Bank Pembiayaan Rakyat Syariah yang operasional dan produknya berdasarkan Al - Qur'an dan hadist. Bank Pembiayaan Rakyat syariah dilarang melaksanakan aktivitas gharar, riba, dholim, dan haram dalam setiap kegiatan usahanya.

\section{Perbedaan Antara BPR Syariah dan BPR Konvensional}

Sumitro (2002) mengidentifikasi ciri - ciri bank syariah yang membedakannya dengan bank konvensional, yaitu :

1. Beban biaya yang disepakati pada waktu akad perjanjian diwujudkan dalam bentuk jumlah nominal yang besarnya tidak kaku dan dapat dilakukan dengan kebebasan untuk tawar menawar dalam batas wajar.

2. Penggunaan persentase dalam hal kewajiban bersifat melekat pada sisa hutang meskipun batas waktu perjanjian telah berakhir.

3. Di dalam kontrak - kontrak pembiayaan, tidak menerapkan perhitungan berdasarkan keuntungan yang pasti (Fix Return) yang ditetapkan dimuka. Bank Syariah menetapkan sistem yang didasarkan atas penyertaan modal untuk jenis kontrak Mudharabah dan Musyarakah dengan sistem bagi hasil (Profit dan Loss Sharing) yang tergantung pada besarnya keuntungan.
4. Pengerahan dana dalam bentuk deposito ataupun tabungn oleh penyimpan dan dianggap sebagai titipan (Wadiah), sedangkan bagi bank dianggap sebagai titipan yang diamanatkan sebagai penyertaan dana pada proyek - proyek yang dibiayai bank, hingga pada penyimpan dana tidak dijanjikan imbalan yang pasti. Namun demikian apabila proyek proyek yang dibiayai bank untung maka penyimpan dana akan memperoleh bagian keuntungan yang mungkin lebih besar daripada tingkat bunga deposito ataupun tabungan yang berlaku pada bank konvensional.

5. Terdapat pos pendapatan berupa pendapatan "Non Halal" sebagai hasil dari transaksi dengan bank konvensional, pos ini biasanya digunakan untuk menyantuni masyarakat miskin yang terkena musibah dan untuk kepentingan lainnya yang bersifat sosial.

\section{Kinerja Keuangan}

Muhammad (2005) Kinerja sebuah perusahaan adalah suatu ukuran yang menggambarkan kondisi keuangan perusahaan. Kinerja perusahaan sangat menentukan bagi preferensi masyarakat baik stake holder maupun bond holder untuk melakukan investasi sangat ditentukan oleh kinerja perusahaan. Dalam menilai kinerja perusahaan banyak indikator yang digunakan, diantaranya financial statement baik berupa neraca yang menunjukkan posisi finansial perusahaan pada saat tertentu, maupun 
Sarasyanti, et al/Jurnal Ekonomi Syariah Teori dan Terapan Vol. 5 No. 4 April 2018: 290-304;

PERBANDINGAN KINERJA KEUANGAN BPRS DAN BPR KONVENSIONAL DI SURABAYA

laporan laba - rugi yang merupakan laporan operasi perusahaan selama periode tertentu. Di samping itu, kinerja juga dapat diukur dengan rasio keuangan yang terdiri dari rasio likuiditas (liquidity ratio), rasio keuntungan (profitability ratio), dan ownership ratio.

\section{Rasio Kinerja Keuangan}

Non Performing Loan

merupakan pinjaman yang mengalami kesulitan pelunasan, baik itu disebabkan karena kekurang tepatan analisis pemberian kredit ataupun dikarenakan kondisi pereknomian yang mengalai ketidakstabilan yang mengakibatkan adanya kegagalan pada sebagian besar kegiatan ekonomi. Rasio ini merupakan indikator kualitas pinjaman. Menurut Gup dan Kolari (2005 : 68) dalam (Prasetyo, 2012 : 11), kualitas pinjaman juga dapat dilihat dari besarnya penghapus bukuan dan Non Performing Loan.

Non Performing Financing (NPF) adalah pembiayaan bermasalah yang terdiri dari pembiayaan yang berklarifikasi kurang lancar, diragukan dan macet. Sedangkan menurut Sudarsono (2007:23), pembiayaan non lancar atau yang juga dikenal dengan istilah NPF dalam perbankan syariah adalah jumlah kredit yang tergolong lancar yaitu dengan kualitas kurang lancar, diragukan dan macet berdasarkan ketentuan Bank Indonesia tentang kualitas aktiva produktif.

Loan to Deposit Ratio (LDR) merupakan rasio yang mengukur kemampuan bank untuk memenuhi kewajiban keuangan yang harus segera dipenuhi. Kewajiban tersebut merupakan call money yang harus dipenuhi pada saar adanya kewajiban kliring, dimana pemenuhannya dilarang dari aktiva lancar yang dimiliki perusahaan (Sudarini, 2005).

Finance to Deposit Ratio (FDR) yaitu rasio yang menunjukkan kemampuan suatu bank dalam menyediakan dana kepada debiturnya dengan modal yang dimiliki oleh bank maupun dana yang dapat dikumpulkan dari masyarakat.

ROA adalah rasio yang menunjukkan kemampuan perusahaan dengan menggunakan seluruh aktiva yang dimiliki untuk menghasilkan laba setelah pajak. Rasio ini penting bagi pihak manajemen untuk mengevaluasi efektivitas dan efisiensi manajemen perusahaan dalam mengelola seluruh aktiva perusahaan. Semakin besar ROA, berarti semakin efisien penggunaan aktiva perusahaan atau dengan kata lain dengan jumlah aktiva yang sama bisa dihasilkan laba yang lebih besar, dan sebaliknya.

Menurut Dendawijaya (2006:122), Net Interest Margin (NIM) adalah rasio yang digunakan untuk mengukur menghasilkan pendapatan bunga bersih, semakin besar rasio ini maka meningkatnya pendapatan bunga atas aktiva produktif yang dikelola bank, sehingga keungkinan suatu bank dalam kondisi bermasalah 
Sarasyanti, et al/Jurnal Ekonomi Syariah Teori dan Terapan Vol. 5 No. 4 April 2018: 290-304;

PERBANDINGAN KINERJA KEUANGAN BPRS DAN BPR KONVENSIONAL DI SURABAYA

semakin kecil.

Net Operating Margin (NOM) yang dapat diartikan sebagai rasio rentabilitas untuk mengetahui kemampuan aktiva produktif dalam menghasilkan laba melalui perbandingan pendapatan operasional dan beban operasional dengan rata - rata aktiva produktif. (Ihsan, $2013: 1011$

CAR oleh Bank Indonesia disebut Kewajiban Penyediaan Modal Minimun Bank (KPMM). KPMM adalah perbandingan antara modal dengan ATMR (Johnson dan Johnson, 1985:331332)

\section{Metode Penelitian}

\section{Pendekatan Penelitian}

Pendekatan yang digunakan pada penelitian ini adalah pendekatan kuantitatif.

\section{Identifikasi Variabel}

Berdasarkan rumusan masalah penelitian, maka variabel dalam penelitian ini adalah rasio keuangan. Rasio ini dinyatakan dalam prosentase. Variabel-variabel yang digunakan dalam penelitian ini adalah NPF (Non Performing Finance), FDR (Finance to Deposit Ratio), ROA (Return on Asset), NOM (Net Operating Margin), CAR (Capital Adequacy Ratio).

\section{Definisi Operasional}

Non Performing Loan merupakan pinjaman yang mengalami kesulitan pelunasan, baik itu disebabkan karena kekurang tepatan analisis pemberian kredit ataupun dikarenakan kondisi pereknomian yang mengalai ketidakstabilan yang mengakibatkan adanya kegagalan pada sebagian besar kegiatan ekonomi Sudarsono (2007:23) Rasio ini merupakan indikator kualitas pinjaman.

Non Perfoarming (NPF) analog dengan Non Performing Loan pada bank konvensional adalah perbandingan antara total pembiayaan bermasalah dengan total pembiayaan yang diberikan kepada debitur. (Prasetyo, 2012:11),

$$
\begin{gathered}
\mathrm{NPL}=\frac{\text { Kredit Bermasalah }}{\text { Total Kredit }} \times 100 \% \\
\mathrm{NPF}=\frac{\text { Total Pembiayaan Bermasalah }}{\text { Total Kredit }} \times 100 \% .
\end{gathered}
$$

Loan to Deposit Ratio (LDR) merupakan rasio yang mengukur kemampuan bank untuk memenuhi kewajiban keuangan yang harus segera dipenuhi. Kewajiban tersebut merupakan call money yang harus dipenuhi pada saar adanya kewajiban kliring, dimana pemenuhannya dilarang dari aktiva lancar yang dimiliki perusahaan (Sudarini, 2005). FDR bertujuan untuk mengukur seluruh jumlah pembiayaan yang diberikan bank dengan dana yang diterima oleh bank. Data ini merupakan data rasio dan diambil secara tahunan.

$$
\begin{aligned}
& \mathrm{LDR}=\frac{\text { Kredit }}{\text { Dana Pihak Ketiga }} \times 100 \% \\
& F D R=\frac{\text { Total Pembiayaan }}{\text { Dana Pihak Ketiga }} \times 100 \%
\end{aligned}
$$

ROA bertujuan untuk mengukur kemampuan bank syariah dalam memperoleh keuntungan (laba sebelum pajak) yang diperoleh dari total aset 
Sarasyanti, et al/Jurnal Ekonomi Syariah Teori dan Terapan Vol. 5 No. 4 April 2018: 290-304;

PERBANDINGAN KINERJA KEUANGAN BPRS DAN BPR KONVENSIONAL DI SURABAYA

yang dimiliki bank tersebut.

ROA $=\frac{\text { Laba sebelum pajak }}{\text { Total aset }} \times 100 \%$

NIM bertujuan untuk mengetahui kemampuan aktiva produktif dalam menghasilkan laba melalui perbandingan pendapatan operasional dan beban operasional dengan rata - rata aktiva produktif.

Net Operating Margin (NOM) yang dapat diartikan sebagai rasio rentabilitas untuk mengetahui kemampuan aktiva produktif dalam menghasilkan laba melalui perbandingan pendapatan operasional dan beban operasional dengan rata-rata aktiva produktif.

$\mathrm{NIM}=\frac{\text { Pendapatan bunga bersih }}{\text { Rata-rata aktiva produktif }} \times 100 \%$

$\mathrm{NOM}=\frac{(P o-D B H)-B O}{\text { Rata-rata aktiva Produktif }} \times 100 \%$

Keterangan:

$\mathrm{Po}=$ Pendapatan Operasional

$\mathrm{DBH}=$ Dana Bagi Hasil

$\mathrm{BO}=$ Beban Operasional

CAR merupakan indikator terhadap kemampuan bank untuk menutupi penurunan aktiva bank sebagai akibat dari kerugian - kerugian bank yang disebabkan oleh aktiva yang beresiko[Johnson dan Johnson, 1985:331332)secara matematis CAR dirumuskan :

CAR $=\frac{\text { Modal Bank }}{\text { Total ATMR }} \times 100 \%$

\section{Jenis dan Sumber Data}

Dalam penelitian ini digunakan jenis data kuantitatif, sedangkan sumber data adalah data sekunder. Data sekunder merupakan data primer yang telah diolah lebih lanjut dan disajikan oleh pengumpul data primer atau oleh pihak lain dan biasanya disajikan dalam bentuk tabel atau diagram (Siagian dan Sugiarto, 2006: 17). Data laporan keuangan perusahaan yang menjadi sampel penelitian diperoleh dari beberapa sumber seperti laporan publikasi yang terangkum dalam situs www.ojk.go.id. Direktori Bank Indonesia yang juga ada di situs www.bi.go.id, dan beberpa sumber lain yang relevan dengan data yang dibutuhkan.

\section{Populasi dan Sampel}

Populasi pada penelitian ini memiliki kriteria yaitu:

1. Bank Pembiayaan Rakyat Syariah dan Bank Perkreditan Rakyat Konvensional di Surabaya.

2. Laporan keuangan Bank Pembiayaan Rakyat Syariah dan Bank Perkreditan Rakyat Konvensional tahun 2014-2016.

\section{Sampel}

Sampel yang digunakan dalam penelitian ini adalah Bank Pembiayaan Rakyat Syariah dan Bank Perkreditan Rakyat Konvensional yang menggunakan laporan keuangan triwulan yang terdapat pada website OJK. Teknik pengambilan sampel dengan menggunakan teknik sampling jenuh. Sampling jenuh adalah teknik penentuan sampel bila semua penelitian yang ini membuat generalisasi dengan tingkat kesalahan yang sedikit atau kecil, sehingga sampel dalam penelitian ini adalah Bank Pembiayaan Rakyat Syariah dan Bank Perkreditan Rakyat Konvensional di Surabaya periode 2014 - 2016.

\section{Teknis Analisis}


Sarasyanti, et al/Jurnal Ekonomi Syariah Teori dan Terapan Vol. 5 No. 4 April 2018: 290-304;

PERBANDINGAN KINERJA KEUANGAN BPRS DAN BPR KONVENSIONAL DI SURABAYA

Penelitian ini memfokuskan pada perbandingan kinerja keuangan berdasarkan rasio keuangan pada Bank Pembiayaan Rakyat Syariah dan Bank Perkreditan Rakyat Konvensional pada periode 2013 - 2016 yaitu dengan menggunakan NPF, FDR, ROA, NOM dan CAR. Untuk menganalisis masalah yang telah dirumuskan dalam penelitian ini ditempuh dengan langkah - langkah sebagai berikut:

1. Menetapkan sampel penelitian. Sampel yang digunakan dalam penelitian ini adalah dua Bank Pembiayaan Rakyat Syariah dan empat Bank Perkreditan Rakyat konvensional yang ada di Surabaya.

2. Menghitung rasio keuangan yang ditentukan dalam penelitian ini.

3. Membandingkan secara langsung kinerja BPRS dan BPR konvensional di Surabaya dengan menghitung selisih dua rata - rata (mean), nilai terbesar (maximum), dan nilai terendah (minimum) selama tiga tahun.

4. Uji Normalitas

Dalam pengujian ini, pengujian normal tidaknya distribusi data akan diuji dengan uji normalitas kolmogorov smirnov, dengan tingat signifikansi yang digunakan sebesar 5\%. Jika sample yang diperoleh berasal dari populasi terdistribusi normal, maka akan dilanjutkan dengan uji parameterik yaitu uji beda $\dagger$ saling bebas (independent $\uparrow-$ test). Jika sampel yang

diperoleh tidak terdistribusi normal, maka pengujian dilakukan dengan uji statistik non parametik (Mann Whitney
Test). Pedoman pengambilan keputusan untuk hasil pengujian normalitas data adalah:

a. Jika nilai signifikasi atau nilai probabilitas $<0,05$ maka olah $\mathrm{HO}$, artinya distribusi data tidak normal.

b. Jika nilai signifikasi

c. atau nilai probabilitas $>0,05$, maka terima $\mathrm{HO}$, artinya distribusi data adalah normal.

5. Melakukan uji hipotesis. Penelitian ini menggunakan uji hipotesis dua sampel bebas (Independent Samples ttest) untuk mengetahui perbedaan NPF, FDR, ROA, NOM, dan CAR pada BPRS dan BPR konvensional data yang terdistribusi normal.

\section{Hasil dan Pembahasan}

Deskripsi Variabel Penelitian

Tabel 1

Hasil Uji Deskriptif

\begin{tabular}{|l|l|r|r|r|}
\hline \multicolumn{2}{|l|}{ Kelompok } & NPF & \multicolumn{1}{l|}{ FDR } & \multicolumn{1}{l|}{ ROA } \\
\hline \multirow{4}{*}{ BPRS } & N & 22 & 22 & 22 \\
\cline { 2 - 5 } & Min & 2.94 & 83.00 & -4.00 \\
\cline { 2 - 5 } & Max & 37.71 & 192.00 & 3.00 \\
\cline { 2 - 5 } & Mean & 14.2082 & 137.603 & -.0336 \\
\cline { 2 - 5 } & $\begin{array}{l}\text { Std. } \\
\text { Dev }\end{array}$ & 11.8102 & 35.1767 & 2.14187 \\
\hline \multirow{3}{*}{ BPR } & N & 3 & 9 & \\
\cline { 2 - 5 } & Min & 0.00 & 58.00 & -5.00 \\
\cline { 2 - 5 } & Max & 33.00 & 102.00 & 119.00 \\
\hline & Mean & 5.9091 & 79.6023 & 4.7841 \\
\hline
\end{tabular}


Sarasyanti, et al/Jurnal Ekonomi Syariah Teori dan Terapan Vol. 5 No. 4 April 2018: 290-304;

PERBANDINGAN KINERJA KEUANGAN BPRS DAN BPR KONVENSIONAL DI SURABAYA

\begin{tabular}{|l|l|r|r|r|}
\hline & $\begin{array}{l}\text { Std. } \\
\text { Dev }\end{array}$ & 7.10292 & $\begin{array}{r}11.0729 \\
43.1397 \\
9\end{array}$ \\
\hline \multirow{4}{*}{$\begin{array}{l}\text { Tota } \\
\text { I }\end{array}$} & N & 110 & 110 & 110 \\
\cline { 2 - 5 } & Min & 0.00 & 58.00 & -5.00 \\
\cline { 2 - 5 } & Max & 37.71 & 192.00 & 119.00 \\
\cline { 2 - 5 } & Mean & 7.5689 & 91.2025 & 3.8205 \\
\cline { 2 - 5 } & $\begin{array}{l}\text { Std. } \\
\text { Dev }\end{array}$ & 8.84659 & 29.6556 & 11.9347 \\
& & 5 & 4 \\
\hline
\end{tabular}

\begin{tabular}{|c|c|c|c|}
\hline \multicolumn{2}{|c|}{ Kelompok } & \multirow{2}{*}{$\begin{array}{r}\text { CAR } \\
22\end{array}$} & \multirow{2}{*}{$\begin{array}{r}\text { NOM } \\
22\end{array}$} \\
\hline \multirow{5}{*}{ BPRS } & $\mathrm{N}$ & & \\
\hline & Min & 8.00 & -0.0619 \\
\hline & Max & 30.00 & 0.2273 \\
\hline & Mean & 19.0591 & 0.040951 \\
\hline & Std. Dev & 7.64952 & 0.0733507 \\
\hline \multirow{5}{*}{ BPR } & $N$ & 88 & 88 \\
\hline & Min & -1.00 & .0270 \\
\hline & Max & 88.00 & .1447 \\
\hline & Mean & 39.4432 & .064550 \\
\hline & Std. Dev & 18.37718 & .0290185 \\
\hline \multirow{5}{*}{ Total } & $\mathrm{N}$ & 110 & 110 \\
\hline & Min & -1.00 & -0.0619 \\
\hline & Max & 88.00 & 0.2273 \\
\hline & Mean & 35.3664 & 0.059830 \\
\hline & Std. Dev & 18.65268 & 0.0424100 \\
\hline
\end{tabular}

Berdasarkan rasio NPF atau NPL, BPR Syariah memiliki rata - rata rasio NPF
(Non Performing Financing) sebesar 14,2082 dengan rasio tertinggi 37,71 dan rasio NPF terendah 2.94. Sedangkan rata rata rasio NPL BPR Konvensional sebesar 5,9091, sedangkan untuk rasio tertinggi 33,00 , dan terendah 0,00 .

Berdasarkan raio FDR atau LDR dari nilai rata - rata, maksimum dan mininimum rasio FDR atau LDR antara BPR Syariah dan BPR Konvensional. BPR Syariah memiliki nilai FDR atau LDR minimum sebesar $83 \%$, dan memiliki nilai maksimum sebesar $192 \%$ dengan memiliki rata - rata $136.3685 \%$, rata - rata rasio FDR pada BPR Syariah diatas $85 \%$ sehingga dapat dinyatakan bahwa BPR Syariah memiliki kinerja keuangan yang kurang baik atau tidak sehat jika dilihat dari rasio FDR. Pada BPR Konvensional memiliki rasio LDR minimum sebesar 58\%, maksimum $102 \%$ dan memiliki rata - rata rasio LDR sebesar $79.6023 \%$, rata - rata rasio LDR BPR Konvensional di bawah $85 \%$ sehingga dapat dinyatakan bahwa BPR Konvensional memiliki kinerja keuangan yang cukup sehat jika dilihat dari sisi LDR, kecuali pada nilai minimumnya.

Pada rasio ROA (Return on Asset) BPRS memiliki rata - rata sebesar -0.2235 dengan rasio tertinggi 3.00 dan rasio ROA terendah -4.00. sedangkan rata - rata ROA BPR Konvensional sebesar 4.9875 dengan rasio ROA tertinggi 119.00 dan terendah sebesar -5.00 .

Berdasarkan rasio NIM atau NOM terlihat dari nilai rata - rata, maksimum dan mininimum rasio NOM antara BPRS 
Sarasyanti, et al/Jurnal Ekonomi Syariah Teori dan Terapan Vol. 5 No. 4 April 2018: 290-304;

PERBANDINGAN KINERJA KEUANGAN BPRS DAN BPR KONVENSIONAL DI SURABAYA

dan BPR Konvensional. BPRS memiliki NOM minimum $-6,1930 \%$, memiliki nilai maksimum sebesar $22,7314 \%$ dan rata rata 4,035963\%, Pada BPR Konvensional memiliki rasio NIM minimum sebesar 2,6965\%, maksimum $14,4735 \%$ dan memiliki rata - rata rasio NIM sebesar 6,455015\%,

Pada rasio CAR memiliki rata - rata rasio CAR sebesar 19.591 dengan rasio CAR tertinggi 30.00. sedangkan rata - rata CAR BPR Konvensional sebesar 39.6625 dengan rasio CAR tertinggi 88.00 dan rasio CAR terendah -1.00.

Uji Asumsi Klasik

a. Uji Normalitas

Tabel 2

Hasil Uji Komolgrov - smirnov

\begin{tabular}{|c|c|c|c|c|}
\hline & \multirow[t]{2}{*}{ Kelompok } & \multicolumn{3}{|c|}{ Kolmogorov-Smirnova } \\
\hline & & Statistic & $\mathrm{df}$ & Sig. \\
\hline \multirow{2}{*}{ NPF } & BPRS & 0.233 & 22 & 0.003 \\
\hline & BPR & 0.223 & 88 & 0.000 \\
\hline \multirow{2}{*}{ FDR } & BPRS & 0.168 & 22 & 0.109 \\
\hline & BPR & 0.076 & 88 & $0.200^{*}$ \\
\hline \multirow{2}{*}{ ROA } & BPRS & 0.231 & 22 & 0.004 \\
\hline & BPR & 0.278 & 88 & 0.000 \\
\hline \multirow{2}{*}{ CAR } & BPRS & 0.195 & 22 & 0.029 \\
\hline & BPR & 0.094 & 88 & 0.053 \\
\hline \multirow{2}{*}{ NOM } & BPRS & 0.240 & 22 & 0.002 \\
\hline & BPR & 0.163 & 88 & 0.000 \\
\hline
\end{tabular}

Sumber : Hasil Olah Data SPSS
Pada Tabel 2 menjelaskan bahwa untuk variabel NPF atau NPL dan ROA antara Bank Pembiayaan Rakyat Syariah dengan Bank Perkreditan Rakyat Konvensional memiliki signifikansi dibawah 0.05 sehingga dapat dinyatakan untuk variabel NPF atau NPL, ROA, NIM dan NOM di kedua kategori tersebut dinyatakan tidak terdistribusi normal. Pada rasio FDR atau LDR antara Bank Pembiayaan Rakyat Syariah dan Bank Perkreditan Rakyat Konvensional memiliki signifikan diatas 0.05 sehingga dapat dinyatakan untuk variabel FDR atau LDR di kedua kategori tersebut dinyatakan terdistribusi normal. Sedangkan untuk variabel CAR pada Bank Pembiayaan Rakyat Syariah memiliki signifikansi dibawah 0.05 sehingga untuk variabel CAR pada Bank Pembiayaan Rakyat Syariah dapat dinyatakan tidak terdistribusi normal, dan untuk Bank Perkreditan Rakyat Konvensional memiliki signifikansi diatas 0.05 sehingga untuk variabel CAR dinyatakan terdistribusi normal.

\section{Uji Beda}

a. NPF atau NPL

Hasil uji beda Mann - Whitney yang dilakukan pada variabel NPF untuk BPR Syariah dan NPL BPR Konvensional, diketahui bahwa nilai signifikansi dari variabel ini adalah sebesar 0.00 yang lebih kecil dari 0.05 sehingga menunjukkan bahwa terdapat perbedaan kinerja kevangan antara BPR Syariah dengan BPR Konvensional pada sisi NPF atau NPL. 
Sarasyanti, et al/Jurnal Ekonomi Syariah Teori dan Terapan Vol. 5 No. 4 April 2018: 290-304;

PERBANDINGAN KINERJA KEUANGAN BPRS DAN BPR KONVENSIONAL DI SURABAYA

b. FDR atau LDR

Berdasarkan uji beda Independet sample t-test yang dilakukan pada variabel FDR atau LDR untuk BPRS maupun BPR Konvensional, diketahui bahwa nilai signifikansi dari variabel ini pada bagian equal variance not assumed adalah sebesar 0,00 . Nilai signifikansi dari rasio ini lebih besar dari 0,05 sehingga menunjukkan bahwa terdapat perbedaan BPR Syariah dengan BPR Konvensional pada sisi LDR atau FDR.

c. ROA

Hasil uji beda Mann - Whitney yang dilakukan pada variabel ROA untuk BPRS dan BPR Konvensional, diketahui bahwa nilai signifikansi dari variabel ini adalah sebesar 0.00 yang lebih kecil dari 0.05 sehingga menunjukkan bahwa terdapat perbedaan kinerja keuangan antara BPRS dengan BPR Konvensional pada sisi ROA.

d. NIM atau NOM

Hasil uji beda Mann - Whitney yang dilakukan pada variabel NOM untuk BPRS dan BPR Konvensional, diketahui bahwa nilai signifikansi dari variabel ini adalah sebesar 0.00 yang lebih kecil dari 0.05 sehingga menunjukkan bahwa terdapat perbedaan kinerja keuangan antara BPRS dengan BPR Konvensional pada sisi NOM.

Variabel NOM memiliki data terdistribusi secara tidak normal, maka pengujian yang dilakukan untuk mengetahui apakah terdapat perbedaan kinerja keuangan antara Bank Pembiayaan Rakyat Syariah denan Bank
Perkreditan Rakyat Konvensional pada variabel ini adalah dengan menggunakan uji Mann - Whitney.

e. CAR

Hasil uji beda Mann - Whitney yang dilakukan pada variabel CAR untuk BPRS dan BPR Konvensional, diketahui bahwa nilai signifikansi dari variabel ini adalah sebesar 0.00 yang lebih kecil dari 0.05 sehingga menunjukkan bahwa terdapat perbedaan kinerja kevangan antara BPRS dengan BPR Konvensional pada sisi CAR.

\section{PEMBAHASAN}

Menurut Rani (2013 : 121) salah satu faktor utama menyebabkan kredit macet adalah nasabah pembiayaan tidak memiliki kesanggupan membayar dan atau memiliki karakter pembiayaan yang buruk. Pembiayaan non lancar juga dapat disebabkan pihak bank memberikan pembiayaan yang tidak memperhatikan dan menilai calon nasabah pembiayaan, berdasarkan prinsip - prinsip pemberian pembiayaan, yaitu $5 \mathrm{C}+1 \mathrm{~S}$. Dapat disimpulkan semakin rendah kualitas pemberian pembiayaan maka menyebabkan peningkatan NPF.

Terdapat pebedaan yang signifikan antara NPF BPR Syariah dengan BPR Konvensional disebabkan oleh pihak manajerial yang ingin meng ekspansikan BPR Syariah sehingga pihak bank banyak memberikan pembiayaan kepada nasabah, namun pada pihak manajemen tidak memperhatikan prinsip - prinsip penilaian pemberian pembiayaan, sehingga NPF pada BPR Syariah lebih tinggi jika dibandingkan BPR Konvensional. 
Sarasyanti, et al/Jurnal Ekonomi Syariah Teori dan Terapan Vol. 5 No. 4 April 2018: 290-304;

PERBANDINGAN KINERJA KEUANGAN BPRS DAN BPR KONVENSIONAL DI SURABAYA

Hasil penelitian ini sesuai dengan penelitian yang dilakukan oleh Sukmana (2016), dimana dari hasil penelitian yang dilakukan diketahui bahwa terdapat perbedaan yang signifikan jika dilihat dari rasio NPF dan NPL.

$$
\text { Menurut Sulistianingrum (2013:31) }
$$

FDR menunjukkan sejauh mana kemampuan Bank Syariah dalam membayar kembali penarikan dana yang telah dilakukannya kepada nasabah deposan. Pembayaran yang dilakukan oleh Bank Syariah kepada nasabah deposan dilakukan dengan mengandalkan pembiayaan yang telah diberikan oleh Bank Syariah tersebut. Dengan kata lain, FDR ini digunakan untuk melihat seberapa jauh pembiayaan kepada nasabah dapat mengimbangi kewajiban untuk segera memenuhi hutang jangka pendeknya kepada nasabah deposan yang ingin menarik kembali uangnya yang telah digunakan oleh bank untuk memberikan pembiayaan tersebut. Rasio ini juga digunakan untuk melihat kemampuan dan kerawanan dari suatu Bank Syariah.

Terdapat perbedaan yang signifikan antara FDR BPR Syariah dengan LDR BPR Konvensional dilihat dari selisih rata - rata FDR dan LDR yang berbeda jauh. Pada Tabel 4.2 rasio FDR pada BPR Syariah memiliki nilai rata - rata sebesar $137,6032 \%$ lebih tinggi jika dibandingkan LDR BPR Konvensional sebesar79,6023\%. Menurut Peraturan Bank Indonesia No. 12/19/PBI/2010 Tentang Giro Wajib Minimum Bank Umum Pada Bank
Indonesia Dalam Rupiah dan Valuta Asing, rasio likuiditas memiliki batas bawah sebesar $78 \%$ dan batas atas sebesar $100 \%$. Perhitungan FDR sendiri merupakan salah satu indikator untuk mengetahui kemampuan likuiditas bank ketika terjadi penarikan dalam jumlah besar.

Terdapat perbedaan yang signifikan pada rasio ROA antara BPR Syariah dengan BPR Konvensional dilihat dari selisih rata - rata antara BPR Syariah dengan BPR Konvensional, tinggi nya ROA ini selaras dengan tingginya LDR pada BPR Konvensional, dan kecilnya NPF BPR Konvensional sehingga dapat dikatakan bahwa penyaluran dana yang dilakukan oleh BPR Konvensional efektif dalam meningkatkan perolehan laba bank.

Menurut Sukmana (2016) rasio ROA bank konvensional lebih baik jika dibandingkan dengan ROA bank syariah, mungkin karena kontribusi dari aset perbankan terhadap total aset nasional. Sampai pertengahan tahun 2014, pangsa pasar bank syariah berdiri di sekitar $5 \%$, dengan pangsa pasar yang kecil, fasilitas yang diberikan kepada pelanggan juga kecil. Selain itu dalam bank syariah, sebelum produk perbankan diluncurkan, bank perlu persetujuan dari Bank Sentral sebagai regulator. Hal ini penting karena Bank Sentral harus melindungi kepentingan konsumen. Bahkan produk juga harus disetujui oleh Dewan Syariah Nasional (DSN) untuk masalah syariah. Hal ini jelas bahwa proses tersebut membutuhkan waktu dan akibatnya berbagai produk perbankan syariah akan 
Sarasyanti, et al/Jurnal Ekonomi Syariah Teori dan Terapan Vol. 5 No. 4 April 2018: 290-304;

PERBANDINGAN KINERJA KEUANGAN BPRS DAN BPR KONVENSIONAL DI SURABAYA

terbaras. Hal ini tidak terjadi dengan bank konvensional sebagai bank yang hanya perlu persetujuan dari satu pihak, yaitu pada Bank Sentral. Mengingat produk terbatas yang ditawarkan pada Bank Syariah, hal ini membuat profitabilitas Bank Syariah tidak lebih tinggi dibanding bank konvensional.

Hasil penelitian ini sesuai dengan penelitian yang dilakukan oleh Sukmana (2016), dimana dari hasil penelitian yang dilakukan diketahui bahwa terdapat perbedaan yang signifikan jika dilihat dari rasio ROA pada Bank Syariah dengan Bank Konvensional.

Menurut Windriya (2014:42) Net Interest Margin (NIM) atau Net Operating Margin (NOM) diproksikan dengan variabel makroekonomi karena analisis sensitivitas parsial digunakan untuk melihat dampak perubahan atas satu variabel asumsi makro, dengan mengasumsikan variabel asumsi makro yang lain tidak berubah (ceteris paribus). Pengaruh sensiitivitas perubahan Net Operating Margin (NOM) terhadap tingkat inflasi mencerminkan seberapa persentase perubahan Net Opertating Margin (NOM) dipengaruhi oleh persentase perubahan tingkat inflasi.

Tingkat inflasi berkaitan dengan jumlah uang beredar, dan salah satu cara mengendalikannya adalah dengan kebijakan moneter melalui tingkat suku bunga. Secara teori perbankan syariah pada bank umum. Dengan begitu, seharusya kondisi tingkat bunga tidak akan berpengaruh secara langsung kepada industri perbankan syariah. Bunga bank merupakan sumber pendapatan dari bank syariah, dengan demikian sistem ini tidak akan berhadapan langsung dengan negatif spread seperti bank konvensional. Fokus pendapatan utama bank syariah adalah seberapa besar bank dapat mgnhimpun keuntungan dari investasi - investasi pada sektor rill. Namun, pada kenyataannya investasi bank pada sektor rill tidak dapat lepas dari dampak inflasi, atau dapat dikatakan bahwa dengan kadar dan cara pengaruhnya yang berbeda inflasi masih berpengaruh pada profit bank syariah. Melambungnya harga barang akan menurunkan konsumsi masyarakat, sehingga keuntungan produsen akan menurun. Hal ini berimbas pada menurunkan aktivitas pembiayaan Bank Syariah, sehingga pendapatan bagi hasil dari pembiayaan juga menurun.

Selama periode penelitian NPF BPR Syariah lebih tinggi jika dibandingkan dengan NPL BRP Konvensional maka menyebabkan penurunan laba yang akan diterima oleh bank. Walaupun jika dilihat dari rasio tersebut antara BPR Syariah dengan BPR Konvensional memiliki nilai lebih dari $2 \%$ yang menyatakan bahwa kedua bank tersebut memiliki kinerja yang baik.

Hasil penelitian ini sesuai dengan penelitian yang dilakukan oleh Ningtyas (2013) dimana dari hasil penelitian yang dilakukan diketahui bahwa terdapat perbedaan yang signifikan jika dilihat dari rasio NIM dan NOM pada Bank Syariah dengan Bank Konvensional. 
Sarasyanti, et al/Jurnal Ekonomi Syariah Teori dan Terapan Vol. 5 No. 4 April 2018: 290-304;

PERBANDINGAN KINERJA KEUANGAN BPRS DAN BPR KONVENSIONAL DI SURABAYA

Terdapatnya perbedaan yang signifikan pada rasio CAR antara BPR Syariah dengan BPR Konvensional disebabkan selisih mean yang cukup jauh pada rasio CAR antara BPR Syariah dan BPR Konvensional. Hasil yang menunjukkan terdapatnya perbedaan pada rasio CAR yang dimiliki oleh BPR Syariah dengan BPR Konvensional juga disebabkan oleh adanya ketentuan dari Bank Indonesia bahwa bank yang beroperasi di Indonesia harus memiliki rasio Kewajiban Pemenuhan Modal Minimum (KPMM) atau CAR dengan nilai minimum sebesar $8 \%$. Sehingga BPR Syariah maupun BPR Konvensional berupaya untuk memenuhi standar tersebut agar mencapai kinerja kevangan yang baik.

Menurut Iswandari (2013) perbedaan tersebut juga dapat dilihat dari kecukupan modal diantara BPR Syariah dengan BPR Konvensional yang sangat terlihat jelas pada struktur modal yang ada, BPR Konvensional memiliki rata - rata modal yang lebih besar dari pada rata rata modal yang dimiliki oleh BPR Syariah. Tinggi rendahnya ROA suatu bank akan mempengaruhi besaran peningkatan modal pada bank tersebut. Hal ini berlaku pada BPR Konvensional yang memiliki rata - rata ROA yang tinggi dibandingkan dengan rata - rata ROA BPR Syariah, sehingga juga mengindikasikan cukup tinggi pula besaran modal yang dimiliki oleh BPR Konvensional dan hal ini akan meningkatkan CAR dari BPR tersebut.

Lebih baiknya kecukupan modal pada BPR Konvensional ini disebabkan oleh lebih baiknya kinerja BPR Konvensional dalam hal penyerapan dana dari masyarakat. Hal ini disebabkan BPR Konvensional muncul lebih lama dibandingkan dengan BPR Syariah, maka banyak nasabah yang masih asing dengan akad-akad yang berada di bank syariah, masyarakat masih beranggapan bahwa BPR Konvensional dengan BPR Syariah memiliki sitem yang sama saja hanya beda nama, maka dari itu masyarakat beranggapan untuk menyimpan dananya dimana saja asal mendapatkan untung.

Walaupun demikan kinerja BPR Syariah patut diapresiasi karena dapat memperlihatkan cukup baik pula dari segi permodalan dengan mecapai rata - rata nilai CAR sebesar $18,9360 \%$, yaiu nilai diatas rata - rata batas ketentuan yang ada, maka kedua jenis bank tersebut termasuk bank dengan kinerja yang baik karena memiliki rasio CAR dengan nilai diatas ketentuan yang ada, namun pada nilai minimum CAR BPR Konvensional memiliki nilai minus yang menandakan bahwa ada BPR Konvensional yang gulung tikar.

\section{Lebih tingginya rasio CAR pada} Bank Perkreditan Rakyat Konvensional dibandingkan rasio CAR pada Bank Pembiayaan Rakyat Syariah disebabna yang disalurkan oleh Bank Pembiayaan Rakyat Syariah telah banyak dialokasikan pada pihak lain, misalnya untuk pembiayaan modal usaha kecil (menurut majalah bank dan manajemen edisi 103 September - Oktober 2008). 
Sarasyanti, et al/Jurnal Ekonomi Syariah Teori dan Terapan Vol. 5 No. 4 April 2018: 290-304;

PERBANDINGAN KINERJA KEUANGAN BPRS DAN BPR KONVENSIONAL DI SURABAYA

Hal tersebut sejalan dengan penelitian Iswandari (2015) yang mengatakan bahwa terdapat perbedaan yang signifikan antara BPR Syariah dengan BPR Konvensional di Yogyakarta.

\section{Kesimpulan}

Berdasarkan hasil penelitian dan juga pembahasan pada bab sebelumnya, maka simpulan yang dapat diambil adalah:

1. Berdasarkan uji beda $(\alpha=0,05)$ pada periode 2014 - 2016 yang dilakukan dinyatakan bahwa pada faktor permodalan rasio Non Performing Finnce (NPF) terdapat perbedaan kinerja kevangan antara BPRS dan BPR Konvensional.

2. Berdasarkan uji beda $(\alpha=0,05)$ pada periode 2014 - 2016 yang dilakukan dinyatakan bahwa pada faktor permodalan rasio Financing to Deposit Ratio (FDR) terdapat perbedaan kinerja keuangan antara BPRS dan BPR Konvensional.

3. Berdasarkan uji beda $(\alpha=0,05)$ pada periode 2014 - 2016 yang dilakukan dinyatakan bahwa pada faktor permodalan rasio Capital Return on Asset (ROA) terdapat perbedaan kinerja kevangan antara BPRS dan BPR Konvensional.

4. Berdasarkan uji beda $(\alpha=0,05)$ pada periode 2014 - 2016 yang dilakukan dinyatakan bahwa pada faktor permodalan rasio Net Interest Margin
(NIM) terdapat perbedaan kinerja keuangan antara BPRS dan BPR Konvensional.

5. Berdasarkan uji beda $(\alpha=0,05)$ pada periode 2014 - 2016 yang dilakukan dinyatakan bahwa pada faktor permodalan rasio Capital Adequancy Ratio (CAR) terdapat perbedaan kinerja kevangan antara BPRS dan BPR Konvensional.

\section{Saran}

Adapun saran yang dapat digunakan untuk penelitian berikutnya adalah:

1. BPRS sebagai bank baru tetap mengembangkan pemasaran terutama kepada nasabah baru.

2. Bagi BPRS memberikan sosialisasi kepada masyarakat yang lebih gencar, krena banyak lapisan masyarakat tidak terbiasa dengan istilah - istilah yang digunakan dalam produk dan layanan perbankan syariah.

3. Bagi BPRS, dalam manajemennya harus semakin memperhatikan pengelolaan resiko perbankan syariah terhadap penyaluran pembiayaan.

4. Bagi BPR Konvensional maupun BPRS diharapkan dapat mengendalikan LDR atau FDR yang ada, karena tingginya FDR atau LDR dapat meningkatkan risiko kredit bermasalah. Maka dari itu bagi BPRS maupun BPR Konvensional diharapkan keduanya lebih berhati - hati dalam penyaluran dana dan memaksimalkan 
Sarasyanti, et al/Jurnal Ekonomi Syariah Teori dan Terapan Vol. 5 No. 4 April 2018: 290-304;

PERBANDINGAN KINERJA KEUANGAN BPRS DAN BPR KONVENSIONAL DI SURABAYA

fungsi manajemen kredit, sehingga penyaluran dana tersebut dapat diikuti dengan peningkatan ROA secara maksimal.

5. Bagi peneliti selanjutnya diharapkan memperpanjang periode penelitian, menambah rasio.

\section{Daftar Pustaka}

Antonio, Muhammad Syafi'i. (2001). Bank Syariah dan Teori ke Praktik. Jakarta: Tazkia Cendikia.

Arifin, Zainul. (2005). Dasar - dasar Manajemen Bank Syariah . Yogyakarta: Pustaka Alvabet.

Dendawijaya, Lukman. 2006. Manajemen Perbankan. Yogyakarta: Ghalia Indonesia

Ihsan, Dwi Nur'aini. 2013.Analisis Laporan Kevangan Perbankan Syariah, Banten: UIN Jakarta Press.

Iswandari, Mona. (2011). KINERJA KEUANGAN BANK PERKREDITAN RAKYAT DAN BANK PEMBIAYAAN RAKYAT SYARIAH: STUDI KASUS di Yogyakarta. 31-45.

Johnso, Frank $\mathrm{P}$, dan Johnson Richard D.1985. Commercial Bank Management . New York: The Dryden Press. h. 331 - 332.

Laksamana. (2009). Account Officer Bank Syariah memahami praktik proses Pembiayaan di Bank Syariah. Jakarta: PT Gramedia.
Muhammad. (2002). Manajemen Dana Bank Syariah. Yogyakarta: Ekonomisia.

Ningtyas, Puspita. 2013.Perbandingan Kinerja Kevangan Bank Konvensional dan Bank Syariah Berdasarkan Analisis Rasio Keuangan. Jurnal. Universitas Brawijaya.

Rizki Yudi Prasetyo 2012 "Pengaruh Risiko Usaha Terhadap Capital Adequacy Ratio (CAR) pada Bank Umum Swasta Nasional Go Public". Skripsi Sarjana tak diterbitkan. STIE Perbanas Surabaya.

Quth, Syahid Sayyid. (2001). Tafsir Fi Zhilalil Quean di Bawah Naungan Al Quran Jilid 1. Jakarta: Gema Insani Press.

Rani, L.N. 2013. Analisis Faktor - Faktor yang Mempengaruhi Non Performing Financing (NPF) Pada Perbankan Syariah di Indonesia. Tesis tidak diterbitkan. Universitas Airlangga Surabaya.

Sukmana, Raditya. (2016). Islamic Banks vs Conventional Banks. An Analysis on Financial Performances, 81 - 90.

Sulistianingrum, Dwi. R. (2013). Analisis Pengaruh Financing to Deposit Ratio (FDR), Dana Pihak Ketiga (DPK), Sertifikat Bank Indonesia Syariah(SBIS), dan Non Performing FInancing (NPF) Terhadap Return on Asset (ROA), Periode Januari 2009 - Desember 2012. Jakarta: 
Sarasyanti, et al/Jurnal Ekonomi Syariah Teori dan Terapan Vol. 5 No. 4 April 2018: 290-304;

PERBANDINGAN KINERJA KEUANGAN BPRS DAN BPR KONVENSIONAL DI SURABAYA

Universitas Islam Negeri Syarif

Hidayatullah.

Sumitro, Warkum. (2002). Asas - Asas

Perbankan Islam dan Lembaga

Terkait (BMI dan Takaful di Indonesia). Jakarta: PT Raja Grafindo Persada, Indonesia.

Windriya, Anafil. (2014). Analisis Pengaruh Faktor Eksternal dan Faktor Internal Bank Terhadap Profitabilitas Bank Umum Syariah di Indonesia (Periode 2008-2013). Semarang: Universitas Diponegoro.

www.bi.go.id 